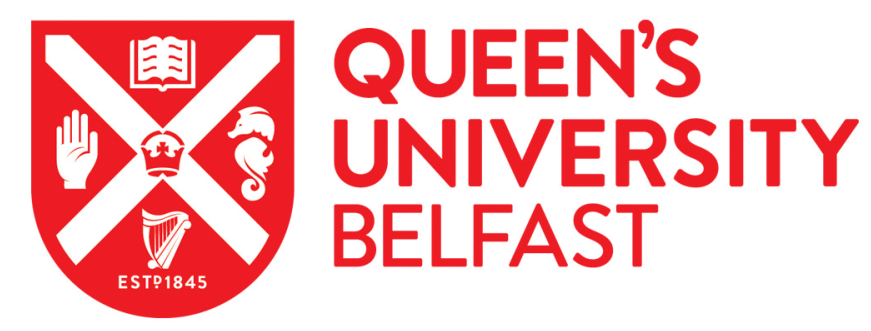

\title{
Complementarity's monopoly on justice in Uganda: the International Criminal Court, victims and Thomas Kwoyelo
}

Moffett, L. (2016). Complementarity's monopoly on justice in Uganda: the International Criminal Court, victims and Thomas Kwoyelo. International Criminal Law Review , 16(3), 503-524. https://doi.org/10.1163/1571812301603003

Published in:

International Criminal Law Review

Document Version:

Peer reviewed version

Queen's University Belfast - Research Portal:

Link to publication record in Queen's University Belfast Research Portal

Publisher rights

Copyright @ 2016 Koninklijke Brill NV

\section{General rights}

Copyright for the publications made accessible via the Queen's University Belfast Research Portal is retained by the author(s) and / or other copyright owners and it is a condition of accessing these publications that users recognise and abide by the legal requirements associated with these rights.

Take down policy

The Research Portal is Queen's institutional repository that provides access to Queen's research output. Every effort has been made to ensure that content in the Research Portal does not infringe any person's rights, or applicable UK laws. If you discover content in the Research Portal that you believe breaches copyright or violates any law, please contact openaccess@qub.ac.uk. 


\section{Complementarity's monopoly on justice in Uganda: the International Criminal Court, victims and Thomas Kwoyelo}

The International Criminal Court was established to tackle impunity for international crimes. Its jurisdiction is premised on states being primarily responsible for investigating and prosecuting those who commit international crimes, with the Court only acting as a last resort. The principle of complementarity has arisen to explain such an arrangement. However, in practice in situational countries before the Court there has not been a perfect implementation of complementarity. Far from it, states have struggled to investigate and prosecute all those responsible, competing with other transitional justice needs and regional politics. This is apparent in Uganda, as the first situation referred to the International Criminal Court (ICC) in 2003. It has been embroiled in controversy of peace versus justice, yet only this year saw the transfer of the first indictee, Dominic Ongwen, before the Court. In the interim the Uganda government has become a critic of the ICC in regional discussions of the Court targeting Africans, despite inviting the Court to investigate crimes in its own country. This article charts the effects of complementarity in Uganda examining the development of domestic legislation, the creation of the International Crimes Division and the first international crimes trial of Thomas Kwoyelo. The emphasis of this article is on a more victim-orientated perspective, as the ICC is often extolled for its 'innovative' victim provisions of participation, protection and reparation. ${ }^{1}$ Moreover, in ending impunity, victim provisions are seen as a way to operationalize the independence and effectiveness of such domestic processes, in the face of political settlements and governmental discretion.

This article begins by giving a brief outline of the northern Ugandan conflict, before discussing ICC intervention. The rest of this paper discusses in more detail Ugandan efforts of positive complementarity. In this author's view victims are a key stakeholder in driving forward the agenda on ending impunity, namely because they can be the most motivated to seek accountability. When it comes to complementarity it is helpful to think of victimorientated complementarity in positive terms in how states are tackling impunity through including victims. Such inclusion involves creating provisions for victims to participate through legal representatives in proceedings that affect their interests, avail of protection measures and are informed of relevant decisions and news. This procedural role can ensure that there is some transparency to the government's compliance with its obligations under the Rome Statute and other international legal obligations. More substantively it is about the state

\footnotetext{
${ }^{1}$ This article draws from research conducted in the past six years on Uganda and field research conducted in Uganda in 2011 and 2015 with interviews and focus groups with key stakeholders and victims, including attendance at the Thomas Kwoyelo trial.
} 
delivering effective and appropriate mechanisms that can satisfy victims' rights to justice, truth and reparations. ${ }^{2}$ As such victims are external stakeholders who can shine a light on the effectiveness of states' investigation and prosecution of international crimes. Of course victims can become frustrated, weary and too unwell, old or perish before justice is realised, emphasising the importance of prompt positive complementarity initiatives. Also it is important to be conscious that the ICC and the Rome Statute is not perfect road map in how to deal with complex and often context specific conflicts, which usually require more local and organic responses to be successfully, constructed within the broad international legal obligations. The context of Uganda represents the challenge of trying to respond to local needs while adhering to international obligations and keeping international donors on board.

\section{A. Complementarity and victims}

Complementarity has been the dynamic watchword of how the ICC navigates state sovereignty and international investigations and prosecutions. It also operates as a catch-all term with different meaning attached by various actors both within and without the Court. At its narrowest, it is a line to demarcate where the ICC will and will not investigate. At its broadest, complementarity is a framework for transitional justice in countries dealing with the aftermath of international crimes. To the extent that complementarity as a term has become overladen with expectation and meaning. Complementarity was originally intended by the drafters of the Rome Statute to protect state sovereignty by recognising their primary responsibility to prosecute and punish perpetrators of international crimes. ${ }^{3}$ The ICC Appeals Chamber has stated that, '[complementarity] strikes a balance between safeguarding the primacy of domestic proceedings vis-à- vis the International Criminal Court on the one hand, and the goal of the Rome Statute to "put an end to impunity" ${ }^{\prime 4}$ More recently Judge Anita Ušacka in the Appeals Chamber has stated that complementarity enables a dialogue between a state and the Court to achieve the goals of the Statute of 'ending impunity for perpetrators' of international crimes. ${ }^{5}$ As such complementarity 'reinforces the principle of international law that it is the sovereign right of every State to exercise its criminal jurisdiction; but it also

\footnotetext{
${ }^{2}$ See Luke Moffett, Elaborating Justice for Victims at the International Criminal Court: Beyond Rhetoric and The Hague, Journal of International Criminal Justice 13(2) (2015) 281-311.

${ }^{3}$ See the Preamble of the Rome Statute; William A. Schabas, Complementarity in Practice: Some Uncomplimentary Thoughts, Criminal Law Forum 19(1) (2008) 5-33, p. 5.

${ }^{4}$ Judgment on the Appeal of Mr Germain Katanga against the Oral Decision of Trial Chamber II of 12 June 2009 on the Admissibility of the Case, ICC-01/04-01/07-1497, 25 September 2009, para.85.

${ }^{5}$ Judgment on the appeal of the Republic of Kenya against the decision of Pre-Trial Chamber of 30 May 2011 entitled "Decision on the Application by the Government of Kenya Challenging the Admissibility of the Case Pursuant to Article 19(2)(b) of the Statute", Dissenting Opinion of Judge Anita Ušacka, ICC-01/09-02/11-342, 20 September 2011, para.19
} 
ensures that the Court can step in to give effect to the goals of international criminal justice. ${ }^{9}$ Thus the ICC is supposed to enable domestic accountability in the first instance.

Where a state is unable or unwilling to prosecute and punish those responsible, the Court can intervene and avoid the continuation of impunity, so called 'negative complementarity'. ${ }^{7}$ As such, the ICC is a 'court of last resort', not first instance. ${ }^{8}$ This is apparent with the language in Article 1 and the Preamble of the Rome Statute that state the Court 'shall be complementary to national criminal jurisdictions', with the Preamble further declaring that in ending impunity, 'it is the duty of every State to exercise its criminal jurisdiction over those responsible for international crimes'. ${ }^{9}$ The principle of complementarity is further substantiated in Article 17, which permits a case to be admissible to the Court's jurisdiction only where a State Party is unable or unwilling to investigate or prosecute those responsible. Read together the Preamble, Articles 1 and 17 establish that under the Statute State Parties are obliged to investigate and prosecute all international crimes. $^{10}$

The Office of the Prosecutor (OTP) has also developed positive complementarity as 'a pro-active policy of co-operation aimed at promoting national proceedings' ${ }^{11}$ This is based on the articles in the Rome Statute on the powers of the Prosecutor and state cooperation. ${ }^{12}$ Under positive complementarity the role of the ICC is to encourage national prosecution to ensure accountability, by states to fulfil their obligations and building domestic judicial capacity. ${ }^{13}$ The 'Rome Statute System' ${ }^{14}$ is supposed to entail investigation and prosecution by both the ICC and State Parties as a 'consensual division of labour' in pursuit of the Rome Statute's mandate to end impunity. ${ }^{15}$ Therefore the ICC is intended to act as a 'catalyst' for

\footnotetext{
${ }^{6}$ Ibid.

${ }^{7}$ John T. Holmes, The Principle of Complementarity, in R.S. Lee (ed.), The International Criminal Court: Elements of Crimes and Rules of Procedure and Evidence (Transnational Publishers 2001), 4178; Informal Expert Paper: The Principle of Complementarity in Practice, OTP, 2003, p. 3.

${ }^{8}$ Nicholas Waddell and Phil Clark, Courting Conflict? Justice, Peace and the ICC in Africa (Royal African Society 2008), p8.

${ }^{9}$ Preamble of the Rome Statute, para. 6, see also paras 4 and 10.

${ }^{10}$ Jann Kleffner Complementarity in the Rome Statute and National Criminal Jurisdictions (Oxford University Press 2008), p251.

${ }^{11}$ The 'Office will encourage genuine national proceedings where possible, including in situation countries, relying on its various networks of cooperation, but without involving the Office directly in capacity building or financial or technical assistance', Prosecutorial Strategy 2009-2012, OTP, 2010, p5.

12 Articles 54(3), 59, 86, 88, 89, and 93, Rome Statute.

${ }^{13}$ Cedric Ryngaert, The Principle of Complementarity: A Means of Ensuring Effective International Criminal Justice, in C. Ryngaert (ed.), The Effectiveness of International Criminal Justice (Intersentia 2009) 145-172, p147.

${ }^{14}$ Prosecutorial Strategy 2009-2012, OTP, 2010, p. 18; see also William W. Burke-White, Proactive Complementarity: The International Criminal Court and National Courts in the Rome System of International Justice, Harvard International Law Journal 49(1) (2008) 53-108.

15 Prosecutorial Strategy 2009-2012, OTP, 2010, p. 5; Informal Expert Paper: The Principle of Complementarity in Practice, OTP, 2003, p. 4
} 
national prosecutions, rather than prosecutorial and judicial workhorse. ${ }^{16}$ Difficulties remain where a state does not have the capacity or willingness investigate or prosecute such crimes and perpetrators. ${ }^{17}$ The Ugandan situation as the first referral to the ICC offers an insightful case study to operation of such positive complementarity, as a country which has the capacity and at times been willing (if not completely).

This article focuses on complementarity from a victim-centred perspective or 'victimorientated complementarity'. ${ }^{18} \mathrm{~A}$ victim-orientated approach to complementarity can have negative and positive aspects. The focus of this article is on the more positive developments in Uganda in terms of complementarity. ${ }^{19}$ As such positive victim-orientated complementarity entails states taking into account victims' rights in investigations and prosecutions of international crimes, such as being able to participate in criminal proceedings, avail of protection measures and claim reparations. ${ }^{20}$ Such an approach is important as it ensure those most affected by such crimes have their interests taken into account and importantly that there is public scrutiny of such processes, improving their effectiveness. The OTP has stated that victim participation in domestic accountability mechanisms is of 'central importance' as it 'helps ensure that policies for combating impunity effectively respond to victims' actual needs and, in itself, "can help reconstitute the full civic membership of those who were denied the protection of the law in the past". ${ }^{21}$ This echoes developments in international human rights law by recognising the role victims as key stakeholders and drivers of justice in moving forward processes to end impunity. ${ }^{22}$

A victim-orientated approach to complementarity involves recognising victims' suffering and rights so as to remedy their harm and the causes of victimisation at the local or national level. The intervention of the Court in a country could demonstrate exemplary fair trial practices to domestic criminal justice systems. Additionally, positive complementarity could encourage the establishment of domestic transitional justice mechanisms alongside criminal courts so as to realise victims' substantive rights, such as truth commissions and reparation bodies. In order to capture the suffering of victims, domestic legislation should be

\footnotetext{
${ }^{16}$ Complementarity: Taking Stock of the Principle of Complementarity: Bridging the Impunity Gap, Report of the Bureau of Stocktaking, ASP eighth session 22-25 March 2010, para.8.

${ }^{17}$ See William W. Burke-White, Implementing a Policy of Positive Complementarity in the Rome System of Justice, Criminal Law Forum 19(1) (2008) 59-85.

${ }^{18}$ Moffett.

${ }^{19}$ The negative aspect involves the analysis of state activity in tackling international crimes for the purposes of admissibility at the ICC. See Moffett.

${ }^{20}$ Moffett.

${ }^{21}$ Interests of Justice, OTP, 2007, p7 and fn. 10, citing the Updated Set of Principles for the Protection and Promotion of Human Rights, report by Diane Orentlicher updating the Joinet Principles, E/CN.4/2005/102/Add.1, 8 February 2005.

2219 Tradesmen v Colombia, Merits, Reparations and Costs, Series C No. 109 (IACtHR, 5 July 2004), paras.260-263; Plan de Sánchez v Guatemala, Merits, Reparations and Costs, Series C No. 116 (IACtHR, 19 November 2004), paras 95-99; Moiwana Community v Suriname, Preliminary Objections, Merits, Reparations and Costs, Series C No. 124 (IACtHR 15 June 2005), paras.203-205.
} 
passed to reflect the gravity of international crimes, so that they can be prosecuted as such. Thus through positive complementarity the ICC could catalyse domestic mechanisms so as to ensure access to justice for victims outside the jurisdiction of the Court. The ICC is not only a last resort for victims, but also a vehicle for developing local access to justice for them. This local perspective framed within an understanding of what justice means for victims will be better positioned to deal with the sensitive issues of remedying international crimes and victim recognition under the oversight of the ICC and Assembly of State Parties. It is also meant to be a procedural benchmark for states dealing with international crimes to prioritise victims' rights in legislation and proceedings and to ensure such crimes are investigated and prosecuted. This has not been the case for victims in the Ugandan situation.

\section{B. Background to the northern Ugandan conflict}

The northern Ugandan conflict has its roots in colonialism and British division of the north and south into different industries and government positions. The more recent factors for the conflict arose in the aftermath of the overthrow of President Milton Obote by a military junta of northern generals in 1985, who were quickly outmanoeuvred by Yoweri Museveni's bush fighters (NRA) in 1986. Fearing reprisals from the NRA after massacres committed by Obote in the Luwero triangle and similar to what Idi Amin had carried out only years before, the members of former military junta retreated to the north, were many continue to fight against the NRA. During this time local armed groups in northern Uganda emerged, such as Alice Lakwena's Holy Spirit Movement and later the Lord's Resistance Army (LRA). ${ }^{23}$

The conflict between the LRA and the Ugandan army (now UPDF) has been raging since 1987 and spread into the Democratic Republic of Congo (DRC), Central African Republic (CAR) and South Sudan, with hundreds of thousands dead. The LRA has been notorious for its brutal attacks on civilians ranging from attacks on villages, cutting off the hands, noses, lips and ears of victims, massacring and burning civilians alive, abducting tens of thousands of adults and children to be used as porters, soldiers or sex slaves. ${ }^{24}$ The Ugandan army (UPDF) is also responsible for carrying out forced displacement of civilians, torture, indiscriminate targeting, and extrajudicial executions as part of its counter-insurgency

\footnotetext{
${ }^{23}$ See Tim Allen, Trial Justice: The International Criminal Court and the Lord's Resistance Army, (Zed Book 2006); Adam Branch, Displacing Human Rights: War and Intervention in Northern Uganda, (Oxford University Press 2011).

${ }^{24}$ Uprooted and Forgotten: Impunity and Human Rights Abuses in Northern Uganda, HRW, 2005, pp. 20-21; UNICEF Uganda Report December 2005; Abducted and Abused: Renewed Conflict in Northern Uganda, HRW, 2003; P. Pham, P. Vinck, and E. Stover, Abducted: The Lord's Resistance Army and Forced Conscription in Northern Uganda, Berkeley-Tulane Initiative on Vulnerable Populations, June 2007.
} 
against the LRA. ${ }^{25}$ As one victim described it "when two elephants fight, it is the grass who suffers'. ${ }^{26}$ This has caused mass suffering of the northern Ugandan population, many of whom have had to live in internally displaced camps for years and 'piny marac' (bad surroundings). ${ }^{27}$ Dolan characterises the impact on civilians as 'social torture... evidence[d] in widespread violation, dread, discretion, dependency, debilitation and humiliation of all which are tactics and symptoms typical of torture, but perpetrated on a mass rather than individual scale. ${ }^{28}$

To stave the violence and enable those abducted to return home the Acholi Religious Leaders Peace Initiative (ARPLI) promoted an amnesty law in 2000. ${ }^{29}$ Although thousands of LRA combatants and abductees have laid down their arms and returned home on the basis of the amnesty, the LRA leadership remains fighting. In 2003 the Ugandan government referred the LRA to the ICC citing difficulties in apprehending them, rather than the requirements of being unwilling or unable to investigate and prosecute their crimes. In 2004 the ICC Prosecutor opened an investigation into the Ugandan situation, and in 2005 released arrest warrants for the top five commanders: Joseph Kony, Vincent Otti, Raska Lukwiya, Okot Odhiambo, and Dominic Ongwen. ${ }^{30}$ Lukwiya, Otti and Odhiambo have been since killed. ${ }^{31}$ Only in January 2015 was the first LRA commander capture with the arrest of Dominic Ongwen in the CAR.

The ICC indictments have had an impact on addressing the conflict in northern Uganda. The most comprehensive way to deal with the conflict in northern Uganda was through the Juba peace process in 2006-2008. Grono and O'Brien suggest that the ICC arrest warrants persuaded the LRA to seek peace in order to avoid prosecution at the Court, as well as prompted the Sudanese government to stop supporting them and instead allow the UPDF to pursue them in southern Sudan. ${ }^{32}$ Although the ICC arrest warrants against the LRA may have been one of the factors that forced them to the negotiating table, many believed the

\footnotetext{
${ }^{25}$ Breaking the Circle: Protecting Human Rights in the Northern War Zone, Amnesty International, 1999, AI Index: AFR 59/001/1999; and Nowhere to Hide: Humanitarian Protection Threats in Northern Uganda, Civil Society Organisations for Peace in Northern Uganda, 2004.

${ }^{26}$ Interview, female victim, 9 July 2011.

${ }^{27}$ Sverker Finnström, Living with Bad Surroundings (Duke Press 2008), p10-14.

${ }^{28}$ Chris Dolan, Social Torture: The Case of Northern Uganda, 1986-2006 (Berghahn Books 2011), p1.

${ }^{29}$ Discussed further below.

${ }^{30}$ Prosecutor v Kony et al., Decision on the Prosecutor's Application for Unsealing of the Warrants of Arrest, ICC-02/04-01/05-52, 13 October 2005.

${ }^{31}$ The ICC has only been able to confirm the deaths of Lukwiya and Odhiambo through a DNA test; see Prosecutor v Lukwiya, Decision to Terminate the Proceedings against Raska Lukwiya, ICC- 02/0401/05-248, 11 July 2007; Uganda's LRA confirm Otti Death, BBC News, 23 January 2008; Prosecutor v Otti, OTP's Submission of Information regarding Vincent Otti, ICC- 02/04-01/05-258, 8 November 2008; and Prosecutor v Odhimabo, Decision terminating proceedings against Okot Odhiambo, ICC02/04-01/05-431, 10 September 2015.

${ }^{32}$ Nick Grono and Adam O'Brien, Justice in Conflict? The ICC and Peace Processes, in N. Waddell and P. Clark (eds), Courting Conflict? Justice, Peace and the ICC in Africa (Royal African Society 2008) 13-20, p15.
} 
indictments were a 'stumbling block' for the peace process, due to the unwillingness of the Court to withdraw the arrest warrants, which led to the process to collapse. ${ }^{33}$ The intervention of the ICC was perceived as unwanted international intervention into a local problem by some traditional and religious leaders, who advocated for 'peace first, justice later' ${ }^{34}$ For victims their views have changed over time on the role of the ICC, but they have been consistent in wanting accountability and reparations. ${ }^{35}$

\section{Domestication of the Rome Statute}

Despite Uganda signing the Rome Statute in 1999 and ratifying it in 2002, it only passed implementing domestic legislation in 2010 , catalysed by it hosting the first review conference of the statute. The Ugandan International Criminal Court Act 2010 facilitates cooperation with the ICC, rather than a more positive complementarity role for the state in tackling international crimes. The statute itself states the purpose of the act is to

'(a) to give the force of law in Uganda, to the Statute; (b) to implement obligations assumed by Uganda under the Statute; (c) to make further provision in Uganda's law for the punishment of the international crimes of genocide, crimes against humanity and war crimes; (d) to enable Uganda to co-operate with the ICC in the performance of its functions, including the investigation and prosecution of persons accused of having committed crimes referred to in the Statute; (e) to provide for the arrest and surrender to the ICC of persons alleged to have committed crimes referred to in the Statute; (f) to provide for various forms of requests for assistance to the ICC; (g) to enable Ugandan courts to try, convict and sentence persons who have committed crimes referred to in the Statute; (h) to enable the ICC to conduct proceedings in Uganda; and (i) to enforce any sentence imposed or order made by the ICC. ${ }^{36}$

The Act itself makes provision for cooperation of the Ugandan government with the ICC in facilitating requests and enabling the Court to sit in Uganda. More importantly the ICC Act 2010 has seen new definitions of international crimes into Uganda's domestic laws, but the Rome Statute and the ICC has had a wider impact on victims and witnesses' rights as well as the creation of domestic institutions.

\section{Clarification of international crimes}

The ICC Act 2010 does not reiterate the international crimes encapsulated in Articles 5-7 of the Rome Statute. Instead the Act just gives effect to them by stipulating any person who

\footnotetext{
${ }^{33}$ See Marieke Schomerus, 'A Terrorist is not a Person like Me': An Interview with Joseph Kony, in T. Allen and K. Vlassenroot (eds), The Lord's Resistance Army: Myth and Reality (Zed Books 2010) 113-131.

${ }^{34}$ See Peace First, Justice Later, Refugee Law Project Working Paper No. 17, July 2005.

${ }^{35}$ See Berkeley Human Rights Center reports: Forgotten Voices: A Population-based Survey on Attitudes about Peace and Justice in Northern Uganda, July 2005; When the War Ends: A Populationbased Survey on Attitudes about Peace, Justice, and Social Reconstruction in Northern Uganda, October 2007; Transitioning to Peace: A Population-based Survey on Attitudes about Social Reconstruction and Justice in Northern Uganda, Human Rights Center, University of California Berkeley, December 2010; Moffett (2014).

${ }^{36}$ Section 2, ICC Act 2010.
} 
commits genocide, crimes against humanity or war crimes as defined in the Rome Statute in Uganda or elsewhere will be liable on conviction on indictment. ${ }^{37}$ That said the inclusion of genocide, crimes against humanity and war crimes breaks some new ground for Ugandan domestic law, at least in interpretative guidance. This is apparent with the crimes of rape, genocide and torture. With regards to rape in Ugandan criminal law, it is defined as 'unlawful carnal knowledge of a woman or girl, without her consent' or through force. ${ }^{38}$ Whereas, under the ICC Act, incorporating the Rome Statute's definition, rape is the invasion of a person through penetration into any part of the body with a sexual organ or object without genuine consent. ${ }^{39}$ Clearly, the Ugandan definition of rape is archaic, ambiguous as to 'unlawful carnal knowledge', excludes male victims and penetration with an object, which would fall under the more ambiguous indecent assault. ${ }^{40}$ Importantly it excludes or at least diminishes sexual acts, such as oral penetration, which would be rape under international criminal law, to indecent assault, a crime against morality, rather than against the personal integrity and dignity of the victim.

Although Uganda signed the Genocide Convention 1948 in 1995, it has yet to criminalise it in domestic law. Thus the inclusion of it within the ICC Act 2010 represents the first time that genocide is criminalised and can be domestically prosecuted. Similarly, up until 2012, torture was not criminalised or defined in Ugandan criminal law. ${ }^{41}$ Torture is prohibited under the Ugandan Constitution, ${ }^{42}$ but this can only give rise to a claim before the Ugandan Human Rights Commission, rather than a basis of criminal prosecution. The ICC Act 2010 could provide interpretative guidance for any prosecution of torture, but given concerns over non-retroactivity it is unlikely to be useable for past crimes. The inclusion of the Rome Statute's definition of torture provides victims with an avenue for redress if the state or nonstate actors use torture where it amounts to genocide, a crime against humanity or a war crime. ${ }^{43}$ In 2012 Uganda passed the Prevention and Prohibition of Torture Act, which defines torture, prohibits and criminalises it. This act gives domestic legal effect to Uganda's obligations under the UN Convention against Torture (CAT), which it signed in 1987. Torture is defined as not only including acts committed by public officials as in the UN CAT, but by private persons, reflecting more the international criminal law position reflected in the Rome

\footnotetext{
${ }^{37}$ Section 7-9, ICC Act 2010.

38 Section 123, Penal Code Act 1950.

39 Article 7(1)(g)-1 Elements of Crimes paras 1 and 2, mirrored in Articles 8(2)(b)(xxii)-1 and $8(2)(\mathrm{e})(\mathrm{vi})-1$.

${ }^{40}$ See Uganda v Kyamusungu Ivan, Criminal Session Case No. 107/96 High Court; Uganda v Odwong Dennis and Olanya Dickson (1992-1993) HCB 71; see Lillian Tibatemwa-Ekirikubinza, Sexual Assaults and Offences against Morality (Fountain Publishers 2005), pp. 4-5.

${ }^{41}$ Torture in Uganda, Redress, 2007.

${ }^{42}$ Article 24. Article 44(a) places freedom from torture in a category as a non-derogable right. See Ojera Denis v Attorney General, UHRC 199/2001, 5 December 2004.

${ }^{43}$ Articles 7(1)(f), 8(2)(a)(ii), and 8(2)(c)(i), Rome Statute.
} 
Statute. ${ }^{44}$ With all these crimes and legislation there is a lack or at least belatedness of domestic implementation of international law, and very little legal basis to prosecute international crimes, given concerns over non-retroactivity. ${ }^{45}$ The ICC Act 201 does not change that possibility, but rather represents a tick box exercise for international donors to ensure Uganda's compliance with the Rome Statute, with little effect on domestic investigation and prosecution of crimes committed by both sides during the conflict. This is apparent in the Thomas Kwoyelo case, discussed further below, where he is charged with a range of domestic offences and crimes under the Geneva Conventions Act 1964, rather than more contemporary understandings of crimes under the ICC Act 2010 or the Torture Act 2012. This is further complicated by the Amnesty Act 2000.

\section{Amnesty Act 2000}

In 2000 the Ugandan Parliament passed the Amnesty Act after sustained advocacy by religious and traditional leaders from northern Uganda. The Amnesty Act 2000 was intended to encourage members of the LRA and other non-state armed groups to 'to end armed hostilities, reconcile with those who have caused suffering and rebuild their communities' ${ }^{46}$ This situation was particularly acute in northern Uganda, where tens of thousands of adults and children were abducted and conscripted by the LRA to fight, porter or be 'wives'. The Amnesty Act 2000 offers a blanket pardon from prosecution to any Ugandan citizen, who since 2 January 1986 has engaged in or is engaging in war or armed rebellion against the Ugandan government. ${ }^{47}$ The Amnesty Act does not distinguish between the gravity of the atrocities, the number of crimes committed, or the seniority of the amnesty reporter. ${ }^{48}$ This is apparent with senior LRA commanders such as Kenneth Banya and Sam Kolo availing of the amnesty. This represents a different approach between the UPDF and prosecutors in Kampala in dealing with LRA, the former seeking to capture Kony and end the conflict through informants, whereas the latter trying to ensure those responsible are held to account. ${ }^{49}$

From the opening of the ICC investigation into the Ugandan situation the Amnesty Act has proved to be a thorn in the side of Uganda's commitment to its obligations under the Rome Statute. As a direct response to the ICC, the Ugandan government introduced the Amnesty (Amendment) Act 2006, to exclude senior leaders of the LRA from the amnesty. Under the 2006 Act the Minister for Internal Affairs could declare Act an individual ineligible

\footnotetext{
${ }^{44}$ Article 1(1) UN CAT; and ibid.

${ }^{45}$ Alternatively Article 15(2), International Convention on Civil and Political Rights 1966, where nonretroactivity does not apply where an office is 'criminal according to the general principles of law recognized by the community of nations.'

${ }^{46}$ Preamble, Amnesty Act 2000.

${ }^{47}$ Section 2, Amnesty Act 2000.

${ }^{48}$ See Louise Mallinder, Uganda at a Crossroads: Narrowing the Amnesty? Working Paper from Beyond Legalism: Amnesties, Transition and Conflict Transformation, 2009, p23.

${ }^{49}$ Discussion with Ugandan ICD prosecutor, November 2014.
} 
for amnesty, by proposing a statutory instrument for the approval of Parliament. ${ }^{50}$ In 2010 the Minister's application to disqualify Kony, Odhiambo, Ongwen, and Thomas Kwoyelo from applying for amnesties was unsuccessful after opposition from northern Ugandan MPs in Parliament. ${ }^{51}$ No further declarations have been made. That said the temporal jurisdiction of the Amnesty Act has been successively renewed in May 2013 and June 2015 both for a further two years. ${ }^{52}$ This has implications for victims' rights and Uganda tackling impunity, or at least delaying such processes.

\section{Procedural guarantees to victims}

Victims' rights have been neglected when comes to addressing the conflict in northern Uganda. However, since the intervention of the ICC in Uganda in 2005, agreements and discussions over dealing with the conflict have been replete with provisions for victims. The prime example is the Juba Agreement and Annexure, where one of its basis that 'essential to acknowledge and address the suffering of victims . . . to promote and facilitate their right to contribute to society. ${ }^{53}$ In addition, The Agreement also deems accountability as crucial in 'preventing impunity and promoting redress'. ${ }^{54}$ The Agreement and Annexure have provisions on victim participation, protection, and reparations, attesting to the influence of the Rome Statute, as the Ugandan Constitution and domestic provisions only provide for a 'right to a remedy', ${ }^{55}$ which has not seen legal development of participation, protection or reparation emerge. the government 'shall promote the effective and meaningful participation of victims in accountability and reconciliation proceedings' ${ }^{56}$ Victims would have also had a right to be 'informed of the processes and any decisions affecting their interests' and entitled to legal representation at the expense of the state. ${ }^{57}$ Moreover, the Agreement stipulated that victims 'dignity, privacy and security' would be respected and protected, with special attention to women and children. ${ }^{58}$

In terms of reparations the Agreement provided for 'rehabilitation; restitution; compensation; guarantees of non-recurrence and other symbolic measures [satisfaction], such as apologies, memorials and commemorations'. ${ }^{59}$ These reparations could be awarded

\footnotetext{
${ }^{50}$ Section 2, The Amnesty (Amendment) Act 2006, inserting Section 2A to the Amnesty Act 2000.

${ }^{51}$ Government withdraws Kony Motion, New Vision, 15 April 2010.

${ }^{52}$ It was not renewed in May 2012 during which time Caesar Achellam surrendered to the UPDF in the DRC.

${ }^{53}$ Clause 8.1, Agreement on Accountability and Reconciliation; see also paragraph 2 of the Preamble.

${ }^{54}$ Paragraph 3, Preamble of the Agreement.

${ }_{55}$ Article 50, Constitution of the Republic of Uganda 1995.

${ }^{56}$ Clauses 8.2 and 24, Agreement.

${ }^{57}$ Clauses 8.2 and 8.3, 3.7 and 3.9 of the Agreement.

${ }^{58}$ Annexure Clause 4(3). Clauses 10-12 of the Agreement, as well as Clauses 4(c), 4(e), 4(f), 8, 13(c), 20, and 24 under the Annexure.

${ }^{59}$ Clause 12; see also Clauses 9.1, 12-14 of the Agreement on Comprehensive Solutions between the Government of the Republic of Uganda and Lord's Resistance Army/Movement, Juba, Sudan, 2 May
} 
individually or collectively. ${ }^{60}$ The Annexure outlines that the government will 'establish the necessary arrangements for making reparations', but this is predicated on the government reviewing the 'financial and institutional requirements for reparations'. ${ }^{61}$ Accordingly, such a reparation programme under the Agreement and Annexure is discretionary, as it may 'not be driven by the needs of victims but by the government's decision on how many resources to allocate to it'. ${ }^{62}$ As of 2015 the Uganda government has not established a reparations programme yet, but has alluded to one as part of its draft Transitional Justice policy.

The Agreement also stipulates different standards of accountability. The LRA is to be prosecuted before 'special justice processes', such as the International Crimes Division (ICD) of the High Court, and traditional ceremonies, whereas government forces will be held to account before existing criminal justice process. ${ }^{63}$ Traditional justice ceremonies, such as mato oput and culo kwor, are meant to provide an 'overarching justice framework' through formal and 'complementary alternative justice mechanisms' ${ }^{64}$ However, these mechanisms could promote impunity and undermine justice for victims, due to their lack of procedural protection for victims, women, children, and other vulnerable groups, as well as their 'inconsistency with established human rights standards' under the Ugandan Constitution. ${ }^{65}$ The Agreement does clarify that these traditional justice mechanisms will only occur after 'full accountability' and therefore they will not be a substitute for prosecutions. ${ }^{66}$ Nonetheless, there remains a risk that different accountability mechanisms within the Agreement and Annexure could impair victims' access to justice and create inequality. This has become apparent with the use of the ICD for only LRA defendants, while UPDF perpetrators are prosecuted behind closed doors in military courts. The Ugandan government has stated that the Agreement and Annexure are not legally binding, owing to Kony's failure to sign them. ${ }^{67}$ Although the ICC had a positive impact on the contents of the Agreement and Annexure, both remain ambiguous on practical implementation of accountability and victim provisions

2007; Clauses 13 and 14 of the Comprehensive Solutions Agreement also recognise the need to restore livestock and compensate land lost during the conflict in Northern Uganda.

${ }^{60}$ Clauses 6.4, 9.2, and 9.3 .

${ }^{61}$ Clauses 16-17, Annexure.

${ }^{62}$ Comprehensive Plan to End Impunity, Amnesty International, AFR 59/001/2008, March 2008, p23.

${ }^{63}$ Clause 4.1.

${ }^{64}$ Mato oput involves 'traditional rituals performed by the Acholi to reconcile parties formerly in conflict' such as drinking the bitter root, culo kwor involves 'compensation to atone for homicide', Clause 1 of the Agreement; see Roco Wat I Acoli Note 30; Clause 5.3 of the Agreement and Clause 19 of the Annexure.

${ }^{65}$ UVF Statement on Juba Annex, 10 April 2008, p3; Articles 32-36 and 42.

${ }^{66}$ Amnesty International, AFR 59/001/2008, p23.

${ }^{67}$ Prosecutor v Kony et al., B. Kainamura, Ugandan Attorney General, Decision Initiating Proceedings under Article 19, Requesting Observations and Appointing Counsel for the Defence, ICC-02/04-01/05354-Anx2, 18 November 2008, p2. 
Since the collapse of the Juba talks in 2008, there has been little realisation of victims' rights in legislation or practice of the ICD. The ICC Act 2010 itself is minimalist when it comes to affording Ugandan victims' any additional rights separate from ICC proceedings. For instance the ICC Act provides for the Ugandan government's specific obligation to cooperate with the ICC in enforcing any reparation order it may make against an individual. However, this does not give rise to a general obligation to provide reparations to all victims of international crimes who suffered during the northern Ugandan conflict. ${ }^{68}$ Similarly the protection of victims and witnesses is limited to providing assistance to the ICC when it requests such measures. ${ }^{69}$ Under the Prevention and Prohibition of Torture Act 2012, victims along with already an avenue of redress to claim compensation through the Ugandan Rights Commission can now also seek rehabilitation and restitution, including medical and psychological care, legal and psycho-social services in cases of trauma, restitution of rights or payment for the provision of services or medical expenses. ${ }^{70}$

Victim can bring private prosecution against a suspect, but this right is curtailed by the discretion of the Director of Public Prosecution to take over and discontinue any criminal prosecution with the consent of the court. ${ }^{71}$ Interestingly international criminal proceedings under the ICC Act 2010 can only be instituted with the consent of the Director of Public Prosecutions. ${ }^{72}$ This could be a way to prevent political prosecutions brought by private individuals against state agents or to prevent accountability for such agents. Private prosecutions are rare in common law systems as victims require the legal knowledge of the law and procedure, access to evidence, and have the money to sustain a case. A member of the ICC staff formerly in Uganda stated that civil society organisations and victims 'don't really have experience in judicial proceedings' and victim participation in criminal proceedings is 'difficult' to explain given Uganda is a common law country. ${ }^{73}$

Really victims' participation in Ugandan criminal trials is limited to the sentencing stage. Under newly introduced Sentencing Guidelines victims can now make a 'victim impact statement' as 'a written or oral account of the personal harm suffered by a victim of crime'. ${ }^{74}$ Statements include the particulars of the offence and victim, as well as the financial, physical,

\footnotetext{
${ }^{68}$ Section 64, ICC Act 2010.

${ }^{69}$ Section 58, ICC Act 2010.

${ }^{70}$ Section 6, Prevention and Prohibition of Torture Act 2012.

${ }^{71}$ Article 120 (3)(b) (c) and (d), Constitution of the Republic of Uganda 1995.

${ }^{72}$ Article 17(1), ICC Act 2010.

${ }^{73}$ ICC official 01, Kampala, June 2011.

${ }^{74}$ The Constitution (Sentencing Guidelines for Courts of Judicature) (Practice) Directions, 2013, para.4. Available at http://www.jlos.go.ug/jlos/index.php/document-centre/sentencing-guidelines/264sentencing-guidelines/file
} 
emotional impact and property lost or damaged. ${ }^{75}$ Victims include 'a spouse, children, parents and guardians of minor victims, siblings, all legal guardians of mentally or physically incapacitated victims. ${ }^{176}$ The draft rules of the ICD provide similar sort of provisions 'the extent of damage caused, in particular, the harm caused to the victims, their families, the community where the case originates, the nature of the unlawful behaviour and the means employed to execute the crime ${ }^{77}$ as well as aggravating factors to include the commission of the crime where the victims is particularly vulnerable or with particular cruelty or multiple victims. ${ }^{78}$ Such victim participation is limited, with issues over charges, evidence and responsibility of individuals are already settled, such input can have little impact on sentencing decisions, representing more emotional than participatory contributions to the process. Moreover, victim impact statements are limited to those victims who are informed of such opportunities and are 'back-ended' to the fraction of cases where a crime ends up with a prosecution.

In terms of victim and witness protection, legislation remains in draft form. The ICC Act 2010 criminalises the interference of witnesses or officials in any proceeding or request of the ICC, up to seven years imprisonment. ${ }^{79}$ Whereas under the Penal Code Act 1950 witness intimidate can carry up to a five-year sentence. ${ }^{80} \mathrm{~A}$ more substantive Witness Protection bill has been in draft before the Ugandan Cabinet since 2011. The latest draft of the bill provides for a Witness Protection Programme for those who give statements in criminal cases or appear in court as witnesses. ${ }^{81}$ It also criminalises revealing the identity of a protected witness with a fine or up to ten years imprisonment. ${ }^{82}$ Clearly for victims they would only be able to avail of protection measures under the proposed bill if they gave a statement or appeared as witnesses, thereby not protecting them all nor intermediaries that may represent them and facilitate their access. Avocat Sans Frontiere (ASF) has been working with the Justice Law and Order Sector (JLOS) on the draft rules of procedure of the International Crimes Division. ${ }^{83}$ The rules include provisions for protective and special measures can be ordered for victims and witnesses.

\footnotetext{
${ }^{75}$ Schedule 1, Sentencing Guidelines 2013. Community impact statements can also be made and filled out by 'the local council officials; (b) the traditional leaders; (c) any interested member of the community; or any other person with information to that effect.'

${ }^{76}$ Ibid. VIS can be completed by '(a) the prosecutor; (b) the investigator; (c) the victim; (d) medical personnel; (e) a probation and social welfare officer; (f) a member of the community; (g) the parent or guardian of a child victim, a spouse, or a dependant or close relative of a victim who is unable to make the statement; or (h) any other person with information to that effect.'

${ }^{77}$ Section 55(2)(c)(i).

${ }^{78}$ Section 55(3)(b)(iii) and (iv).

${ }^{79}$ Article 16, ICC Act 2010.

${ }^{80}$ Section 103.

${ }^{81}$ The Witness Protection Bill, 2011, draft 7th October 2011 (on file with the author).

${ }^{82}$ Section 26.

${ }^{83}$ See Complementarity in Practice in Uganda: Speech by Justice Moses Mukiibi, Head, International Crimes Division, Uganda, July 2014, Legal Eye on the ICC, August 2015.
} 
Under the ICD draft rules protective measures include hearing conducted in private (in camera), redacting the personal details of a victim, witness or other person at risk, prohibition of disclosure by the prosecution, defence or other participant in proceedings, testimony provide by electronic or other special, including visual or audio distortion of witness or victim use of live streaming or pseudonyms. ${ }^{84}$ Protective measures are to be made, whenever possible, with the consent of the victim or witness. The prosecution, defence or a witness, victim (or their counsel), or by the court's own motion request protective measures for any risk associated with the testimony given by a witness ${ }^{85}$ Special measures can be used for traumatised victims or witnesses, children, elderly persons, those with disabilities or a victim of sexual violence. ${ }^{86}$ Such special measures can include questioning of a witness or victim should avoid any harassment or intimidation, as well as judges sitting closer to the victim, counsel not wearing gowns, limiting the number of persons present, holding the hearing in less formal surroundings, and providing separate waiting rooms and facilities for defence and prosecution witnesses to 'ensure that they are not exposed to potentially distressing encounters during the trial. ${ }^{97}$ Protective measures can be made to last after the trial. $^{88}$

Accordingly, Ugandan victims remain very much disenfranchised in terms of their rights. Although this is a common refrain in common law countries, with the Ongwen case at the ICC victims will be segregated between those with rights to participation, protection and reparation at the Court and the majority of those outside the narrow charges. It could be argued that victims may see more value in traditional justice mechanisms that bring justice more closer to them in terms of physical proximity and cultural relevance, such as mato oput. ${ }^{89}$ However, from victims and victim groups I have spoken to traditional justice remains only a part of dealing with the past, with concerns that those responsible pay reparation and the most responsible perpetrations in LRA and government punished. ${ }^{90}$ The draft Transitional Justice policy recognises the rights victims have in international law and under the Ugandan Constitution, in particular those relating to reparations, but do not fully victims' rights as a clear guide through the process. Really victims' rights should include both procedural and substantive aspects. ${ }^{91}$ In other words, victims should have legal entitlements, and thereby

\footnotetext{
${ }^{84}$ Section 40 (9), draft ICD rules (on file with the author).

${ }^{85}$ Section 40 , draft ICD rules

${ }^{86}$ Section 41, draft ICD rules.

${ }^{87}$ Section 41(7).

${ }^{88}$ Section 57.

${ }^{89}$ See Martien Schotsmans, Official Complementarity: a Case Study on Northern Uganda, in E. Brems, G. Corradi, M. Schotsmans (eds.) International actors and traditional justice in Sub-Saharan Africa : policies and interventions in transitional justice and justice sector aid, (Intersentia 2015) 71-83.

${ }^{90}$ See also Sarah Nouwen, Complementarity in the Line of Fire The Catalysing Effect of the International Criminal Court in Uganda and Sudan, (CUP 2013), p158.

${ }^{91}$ See Luke Moffett, Justice for Victims before the International Criminal Court, (Routledge 2014).
} 
guarantees, that they can participate in process that affect their interests, protection measures and keep informed, with special measures for vulnerable groups. In substantive rights terms there in continuing inaction to guarantee and ensure truth, justice and reparations. Complementarity and the ICC has so far not seen the delivery of a comprehensive way to deal with the conflict in Northern Uganda, just a narrow conception of justice as prosecution of a few suspects, such as the Thomas Kwoyelo case discussed below.

\section{International Crimes Division}

The Juba Annexure of the Accountability and Reconciliation Agreement specified a special War Crimes division of the High Court to be created to try individuals who are alleged to have committed serious crimes during the conflict ${ }^{2} \cdot{ }^{92}$ Despite the collapse of the Juba peace process, the Ugandan government set up the War Crimes Division (WCD) in July 2008 to investigate and prosecute international crimes, so as to fulfil its obligations under the ICC. ${ }^{93}$ This was renamed in 2011 as the International Crimes Division with jurisdiction over 'genocide, crimes against humanity, war crimes, terrorism, human trafficking, piracy and any other international crime' under the Penal Code Act 1950, Geneva Conventions Act 1964 or the ICC Act $2010 .{ }^{94}$ So far there are nine cases before the ICD, mostly in relation to human trafficking, treason and terrorism. ${ }^{95}$ However, it has been marred by one its most skilled and proficient prosecutors Joan Kagezi being assassinated in March 2015, raising concerns that if it cannot protect its own staff, how will it protect victims and witnesses.

Foreign donors have driven the creation of the ICD with international civil society. There have been numerous training exercises for Ugandan judicial, prosecutorial and diplomatic staff, many of whom have been involved in international seminars and conferences representing the success story of the creation of the ICD and passing of the ICC Act 2010. As one government official stated that while there has been much capacity building around the Rome Statute in Uganda 'it has influenced a lot of what has taken place in the area of formal prosecutions' and helped to create 'a real appreciation of the importance of witness protection and learning how to do risk assessment. ${ }^{96}$

These individuals are now well versed in the provisions and operationalization of the Rome Statute in the domestic context. This is apparent in the Kwoyelo case were conflicts with domestic and international law saw the Supreme Court judges navigate a way through

\footnotetext{
92 Para.7.

${ }^{93}$ The High Court (War Crimes Division) Practice Direction of 2008.

${ }^{94}$ The High Court (International Crimes Division) Practice Direction, Legal Notice No. 10 of 2011, para.6(1).

${ }^{95}$ Kasande Sarah Kihika and Meritxell Regué, Pursuing Accountability for Serious Crimes in Uganda's Courts Reflections on the Thomas Kwoyelo Case, International Centre for Transitional Justice Briefing, January 2015, p3. Uganda v Umutoni [2014] UGHCICD 1 (16 October 2014).

${ }^{96}$ Interview Uganda official 03, April 2015.
} 
the international obligations of the Rome Statute and Amnesty Act. Thomas Kwoyelo was a senior LRA commander, captured by the UPDF in Garamba National Park in the DRC in 2006. Although he claimed an amnesty after being captured he was transferred back to Uganda for trial in Gulu in July 2011. The trial was suspended after the first day, due to Kwoyelo constitutional appeal. In 2011 the Constitutional Court accepted Kwoyelo's claims of discrimination as other more senior commanders had been accepted for amnesty and dismissed the case against him. ${ }^{97}$ However, the Supreme Court overruled this in April 2015. The Supreme Court held that,

Any crimes committed that were not necessitated by the furtherance of the war or rebellion were not a subject of amnesty under the Amnesty Act. They were not political offences but crimes committed on members of society. To allow them, would mean that crimes committed out of malice or even personal vendetta would be granted amnesty. Willful murder of civilians is a crime against humanity which, in my view, cannot be granted amnesty under the Laws of Uganda particularly the Geneva Conventions Act, and the Amnesty Act does not purport to do so. In that regard it is my considered view that the Amnesty Act is not inconsistent with Uganda's International treaty obligations. ${ }^{98}$

As such coming out of the bush and claiming amnesty must be voluntary, rather than an afterthought once captured, as 'mere renunciation by a person in detention for participation in war or armed rebellion and intention to apply for amnesty are not sufficient to grant such a person amnesty. ${ }^{99}$ Also requires a DPP certification that the amnesty reporter is first eligible, and then determine that there are no outstanding criminal charges outside of the scope of the amnesty. Although this decision allows the case against Thomas Kwoyelo to proceed, the Amnesty Act still remains in effect and there is a lack of transparency as to which perpetrators and victims will see justice as a result.

In terms of victims' rights, the International Crimes Division has not integrated victim provisions under the Agreement and Annexure. Beyond appearing as witnesses, victims are unable to participate in the Ugandan crimes justice system, as it is based on the adversarial trial in common law, with their victimisation only being recognised upon a successful prosecution. Although the ICD is dealing with international crimes, debates on victim participation have been too readily dismissed as incompatible with the adversarial trial tradition and would prejudice juries against the defendant. However, the ICD sits in the High Court, which does not use juries and the inexperience of judges and other legal practitioners with victim participation could be addressed by training and regulations of proceedings. In

\footnotetext{
${ }^{97}$ Thomas Kwoyelo v. Uganda, Constitutional Petition No. 036/11, 22 September 2011.

${ }^{98}$ Uganda v Thomas Kwoyelo, Constitutional Appeal No. 01 of 2012, 8 April 2015, per Justice Katureebe, p43.

${ }^{99}$ Justice Dr Kisaakye, ibid. p73.
} 
the Kwoyelo case victims were unable to participate in person or through a legal representative, instead consulted through limited and ad hoc outreach. ${ }^{100}$

That said the draft rules of the ICD do provide for victims to participate, but under the heading of 'Judgment and Sentencing', indicating that victims' role will be limited to their views on harm. However, other provisions refer to victims 'participating in the different phases of the proceedings' or 'all stages of the proceedings'. ${ }^{101}$ The draft rules stipulate the Registrar will notify victims and witnesses who are interested in participating in proceedings, and the Trial Panel may decide if victims' counsel if entitled to attend and participate in 'accordance with the terms of [its] ruling'. The Uganda Victims' Foundation notes the ambiguity of what stage and role victims can participate, and should instead be at the beginning of criminal proceedings, rather than at the end. ${ }^{102}$ In general terms the ICD is tasked with making any direction or order to take into account 'the needs of all the victims and witnesses and in particular, children, elderly persons, persons with disabilities and victims of sexual or gender violence', but it remains unclear how enforceable such direction are in taking victims' needs into account. ${ }^{103}$ For the few days that the Kwoyelo has had public hearings, they have been split between Gulu and Kampala. With the opening of the Kwoyelo trial in the Gulu high court, while in close proximity to the crimes he committed, the courtroom was packed with lawyers, journalists, donors and academics, with most victims left standing squashed into the doorway or outside. This is perhaps a metaphor for victims in the ICD, left on the fringes or side-lines looking in, but not part of the process, taking account of their needs or benefitting from it.

The draft ICD rules also provide for reparation and compensation where the accused is convicted, the Trial Panel is obliged to take into account the views of the victims. ${ }^{104} \mathrm{In}$ addition to these provisions, the ICD Registrar is tasked with: providing notification to victims or their counsel, assisting victims in obtaining legal advice and organise their legal representation; providing counsel of victims with assistance, information and adequate support in protecting victims' rights, assisting victims in participating in different phases of the proceedings, and taking a gender-sensitive measure to facilitate participation of victims of sexual violence. ${ }^{105}$ The Registrar is also responsible for informing victims of available protection measures, made aware of decisions of the Court, which may have an impact on their interests, and keep a special register for victims who have participated before the ICD. ${ }^{106}$

\footnotetext{
${ }^{100}$ See Benchmarks for Justice for Serious Crimes in Northern Uganda, HRW, 2011, p22-25.

101 Section 59(1)(d) and (e).

102 Uganda Victims' Foundation, Statement on the draft Rules of the International Crimes Division June 2015.

103 Section 39(1).

104 Section 56.

105 Section 59(1).

106 Section 59(2) and (3).
} 
In all, although there are clear efforts of the ICD to do justice for international crimes there is 'norm distortion' in how impunity is tackled with victims being disregarded in practice. ${ }^{107}$ As one civil society leader felt that victims played a 'very peripheral role' in the ICD, 'we say we do these things for victims, but where are they in this whole equation?' ${ }^{108}$

\section{Conclusion}

At first blush complementarity in Uganda could be judged a success. There has been a raft of legislation, the creation and operation of a specialised international crimes division, and trials on going. From a more critical perspective from the ground, the situations of victims has not changed, those prosecuted are 'small fish' and legislation is prospective and non-retroactive to the northern Ugandan conflict, meaning it is of little use in tackling impunity for crimes committed during this time. For victims their plight has not been lessened, they still seek truth, accountability and reparations for the harm they have suffered, key things that are meant to be redressed in tackling impunity for such serious crimes. As such although complementarity has monopoly on justice or at least a premium over wider transitional justice processes, it is a narrow focus that has limited impact and value for victims. Although the ICC has not been directly leading these developments, the importance of complementarity as the buzzword for rule of law and tackling impunity has been prioritised by foreign donors and civil society, neglecting victims' needs in practice. Perhaps this reflects the overladen expectation and multi-perspective understanding of complementarity, that in dealing with international crimes it is not the be all and end all discussion of justice, but rather a small part that needs other processes to horizontally complement investigations and prosecutions in domestic processes. In order to ensure the legitimacy and success of the future development of complementarity great attention needs to be given to victims' rights to ensure the transparency and effectiveness of such processes, but to also widen the scope of justice to tackle a wide scope of crimes committed and different mechanisms to address them. Complementarity is one part of the puzzle of dealing with international crimes, it should not eclipse the wider needs of victims and society of pursuing justice, truth and reparations.

\footnotetext{
${ }^{107}$ Nouwen p241-243.

${ }^{108}$ Civil society member, Kampala, July 2011.
} 